\title{
Harjito
}

Universitas PGRI Semarang, Semarang, Central Java, Indonesia

harjito@upgris.ac.id

\section{Loyalty and Javanese Women in Indonesian Folktales for Children}

Pregledni rad / review paper

Primljeno / received 7. 2. 2019. Prihvaćeno / accepted 12. 6. 2021.

DOI: $10.21066 /$ carcl.libri.10.2.3

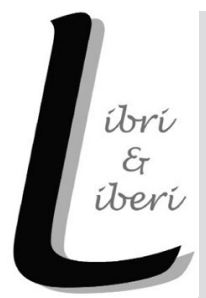

This study analyses the representation of the loyalty of Javanese women in Indonesian folktales for children. We apply a textual analysis from the perspective of feminism and some elements of the literary sociology approach to the analysis of four Indonesian folktales. We conclude that in Indonesian folktales Javanese women are obliged to be loyal to rulers and institutions - which are functionally one and the same. Javanese women who display loyalty often earn symbolic and other benefits, while those who are disloyal or defiant meet a tragic end. The voices of women are not conveyed by the authors of the analysed texts. Therefore, Indonesian folktales impress upon young readers, particularly children, the notion that loyalty to the state and authorities is of paramount importance.

Keywords: relation, representation, the authorities, context, voice

In Indonesia, discussions on the status of women in society have become more pronounced, not only in daily life but also in political and academic spheres. Mainstream media outlets increasingly cover women's issues on television, which has triggered wider debate on whether women can pursue careers without neglecting their obligations as housewives. Indeed, as both housewives and workers, women possess dual roles which put them under more stress than their husbands, who are obligated only to make a living for their family.

Women are not only the caregivers in their families, but, in households under financial strain, they may also be breadwinners (Ismawati 2013: 10). Mothers are not only responsible for managing their households and caring for the family, but they must also work to help sustain their families financially. 
Women-related subjects have become increasingly prevalent in academic scholarship and research. In the government, there are now several female heads of ministries, an indication of women's increasingly important role in politics. The significant role of women in this area was also recognised in earlier times. ${ }^{1}$

The aim of this paper is to establish how Javanese girls and women are represented in Indonesian folktales for children with respect to the notion of loyalty, whether to men in their surroundings or to rulers and institutions. We also address the issue of representations of women's voices. An analysis of four Indonesian folktales is conducted from the point of view of feminist criticism and considering the messages sent to child recipients. The reasons that Javanese women are expected to be loyal are interpreted in the context of the patriarchal culture behind the tales.

\section{Representations of ideologies and starting points}

Relating to power in literary texts, Katrin Bandel (2013) analysed the representation of Javanese women in the short stories "Dia yang Menyerah" [She Who Gave up] by Pramoedya Ananta Toer (1952) and "Sri Sumarah" [Sri Who Surrenders] by Umar Kayam (1975). It is notable that women's roles are portrayed differently by the two Javanese authors in these two stories. Umar Kayam strengthens the views of the powerful perpetuating dominant concepts of Javanese culture that became mainstream during the New Order era (1966-1998). In contrast, Pramoedya Ananta Toer continuously resists dominant Javanese cultural norms by criticising widely accepted values which she considers detrimental to society. He portrays Javanese culture as pluralistic and endorses a flexible and open concept of ethnicity.

Similar to Bandel, Harjito (2014) also comments on the issue of the loyalty and independence of Javanese women in traditional stories. Women's independence is commonly referred to when women are abandoned by their seemingly good husbands, either as a result of unresolved grievances or the death of the husband. Harjito identifies three forms of independence among Javanese women: nurturing and supporting their children, becoming leaders, and being loyal to their ruler. Women are obligated to support their children, as it is a commonly held belief in the Indonesian context that having children and being a mother are integral to womanhood (Harjito 2016).

In connection with this, the notion of nationalism also needs to be raised. Nationalism refers to groups of people who share a common bond which unites individuals in a greater collective identity. Nationalism binds a group of people emotionally into one unit as a community (Sargent 1987: 15-24). Nationalism also celebrates the shared religion, ancestry, language, culture, and territory of a group of

1 At the time of the Java War (1825-1830), a guerrilla war following the resistance led by the Javan Prince Diponegoro against the Dutch colonialists, Raden Ayu Yudokusumo and Raden Ayu Serang were two notable women. Raden Ayu Yudokusumo demonstrated her greatness when she arranged attacks on the Chinese community in Ngawi on 17 September 1825. Similarly, Raden Ayu Serang was a well-known member of the Sunan Kalijogo family as well as a prolific fighter and socialite. She had an important influence on the people of Serang and Demak (Carey and Vincent Houben 2016: 27-33). 
people. Nationalism is therefore an ideology that is the basis of all nations, facilitating their organisation as free and autonomous entities (Riff 2001: 193-194).

In the era of globalisation, the physical borders which separate countries are integral for a country to maintain authority over its territory. Indeed, disputes over borders can lead to confrontations between countries. However, owing to the democratisation of communication through the internet, the products of national cultures regularly cross borders, influencing cultures far beyond their country of origin. For example, someone in Indonesia can use social media technologies such as Facebook, Twitter, or WhatsApp to easily communicate with friends located in other countries. Hence, networked communication has made it possible for people to adopt alternative religious, cultural, social, or political ideologies which were previously not known to them. Such exchanges of culture often result in a clash of ideologies-provoking a re-evaluation of natural nationalism by individuals and countries. Nevertheless, nationalism is still considered important both by individuals and communities.

Loyalty can therefore be defined as complete allegiance by an individual to certain institutions, regions, kingdoms, or countries. In the Indonesian Dictionary (Pusat Bahasa Departemen Pendidikan Nasional 2008), loyalty is listed as interchangeable with the term "obedient". Moreover, an individual is often called loyalist or follower. In government and politics, individuals are often referred to as "loyal, faithful, and enduring supporters of the government". However, in this paper, loyalty is defined as someone's loyalty to an individual or an institution. An institution may refer to a particular community, nation, kingdom, or country. Therefore, we understand loyalty to the nation or kingdom to be equal to nationalism.

This paper also intends to explore the meaning of "loyalty" when used to talk about Javanese women. The interrelation between the social class and loyalty of Javanese women is also taken into account. In Java, a clear hegemonic understanding of loyalty which demands obedience and subservience is communicated to individuals. Anything contrary to loyalty is stigmatised as rebellion and an "unwillingness to follow orders" and "opposing" the authorities (Pusat Bahasa Departemen Pendidikan Nasional 2008: 130).

\section{Methodology and corpus}

This paper takes a feminist perspective and sociology of literature approach. Feminism is an ideological category that aims at gender equality and emancipation which has a dominant influence on the media and audiences (Pocha 2010: 70; Young 2010: 263; Udasmoro 2011: 4). Feminism brings together various ideas that are similar in three ways, namely gender, patriarchy, and women's knowledge. According to Maggie Humm, gender is a social construct that oppresses women more than men; patriarchy is the formation of this construct; and women's knowledge is the basis for the formation of a non-sexual society in the future (2009: 331-332). In the view of multicultural feminism, all women are not perceived equally in a country, but depending on race, class, sexual preferences, age, religion, education, occupation, marital status, or health condition 
(Tong 2008: 309-310). Feminist perspectives are necessary to see how the relationship between women and men, as well as the relationship between women and other women, functions. To sharpen the analysis and relate it to this context, the sociology of literature approach is used, which assumes the existence of a relationship between social reality and social text (Damono 2003: 2, 7), whereby the texts of the stories reveal commonly held assumptions concerning social reality. In this paper, the constructs considered are social class and age.

We analyse four Indonesian folktales written down by contemporary authors and published in the 2000s, but the plots of all these stories are set in the past. These are: (1) "Legenda Ki Ageng Mangir Wanabaya" [The Legend of Ki Ageng Mangir Wonoboyo] (hereinafter: LKA) by James Danandjaja (2001); (2) "Punden Mbah Kendil" [Grandma Kendil's Grave] (hereinafter: PMK) by Parpal Poerwanto (2009); (3) "Mbah Suto Bodo" [Suto Bodo's Grandma] (hereinafter: MSB) by Yudiono and Mulyono (2005); and (4) "Dewi Siti Sarijati" [Miss Siti Sarijati] (hereinafter: DSS), by Kusaeri YS (2009). The first two titles, LKA and MSB, recount stories set during the Mataram Kingdom and the reign of Panembahan Senapati Ingalogo in 1584-1601 (cf. Ricklefs 2009: 84-96). PMK tells about the events that happened in the period 1726-1795, during the life of Prince Sambernyowo (cf. Ricklefs 2018). The last of the four texts, DSS, tells a story from the era of the Majapahit Kingdom in the $13^{\text {th }}-15^{\text {th }}$ century (cf. Ricklefs 2009: 71; Munoz 2009: 381-410).

These texts were selected according to two criteria. Firstly, the texts needed to deal with themes related to loyalty among female characters (in particular, Dewi Pembayun, Nyai Sutawanengraga, Mbok Kendil, or Dewi Siti Kolifah). Secondly, the selected texts had to be set in Java. For example, LKA and MSB are located in Pati, while PMK is set in Wonogiri. The location of the story in DSS is Rembang. Rembang, Pati, and Wonogiri are locations in Java. Thus, the four texts analysed are all set in Java, Indonesia.

Indonesian traditional stories can be classified into the following categories: fables, folk stories, myths, legends and hero stories, and epics (cf. Lukens 2003: 24-27). Moreover, traditional works of literature with no known author or date of creation are also often referred to as folk literature (Nurgiyantoro 2005: 32-33). In this study, we consider folktales to be folklore stories with no known author or date of creation and that were originally passed down orally. These folktales are set in Java, use the Indonesian language, and were created by Indonesians. Our study also focuses on folktales written for children with thematic elements related to children.

Data collection for this study entailed collecting books, articles, and other information related to our research questions. We primarily focus on the aspects of loyalty of Javanese women and use qualitative research methods as appropriate for this kind of research, i.e., in the application of feminist social science methods in the research of children's literature (Clark 2002). ${ }^{2}$

2 Clark (2002: 285-286) questions "counting" as a quantitative research method which values the potential to generalise and reminds us of the importance of the qualitative method which is more highly valued in much of social science discourse. 
Before the actual analysis, it might be useful to provide a context for the appearance of the analysed texts and to offer a short overview of the history of Indonesian folk tales.

\section{Popular folk tales - a historical overview}

The presence of Indonesian folktales for children can be traced to the missionary Justus Heurnius of the Dutch Reformed Church in 1624 who brought a printing press to Indonesia with the aim of printing manuscripts, religious treatises, and textbooks for missionary schools. According to Christantiowati (1996: 13-55), Indonesian children's reading texts are those texts which are published in Indonesia and which are read by and intended for Indonesian children. In 1862, Moehamad Moesa's Syair dan Fabel Sunda [Sundanese Verses and Fables] was published, which used Sundanese in Javanese script. In 1863, the Dongeng-Dongeng Toeladan [Model Fairy Tales] by Prawira Koesoemah appeared in Sundanese. In 1875, the book Hikajat Robinson Crusoe [The Story of Robinson Crusoe] was translated by A.F. van de Wall, a translation of Daniel Defoe's story. In 1885, Lie Kim Hok wrote Sobat Anak [Child Friend]. In 1914, Hikajat Pelanduk Djinaka [The Funny Story of the Mouse Deer] was published, written by Soekanto SA. An important work that also needs to be mentioned is Pemandangan dalam Doenia Kanak-Kanak [The World of Children] written by Mohammad Kasim, published in 1924 and reprinted eight times by 1977. Besides, during the period 19171942, traditional folk literature was quite dominant, with the publication for example of Tjeritera si Kantan and Sjair Poelau Belitoeng [The Story of the Kantan and The Poetry of Belitoeng Island] by H. St. Ibramin in 1922.

There are two reasons for the extensive publishing of folklore writing at that time. One was the policy of the colonial government publisher Balai Pustaka to publish books containing ancient stories written by Indonesians. Secondly, since its policy is to print and disseminate old stories that are liked by the community, the most common themes were banner stories, sagas, and folk tales (Bunanta 1998: 66-67). In general, until 1942, the types of children's books published were fiction which included traditional folk literature, fantasy, as well as realistic and non-fiction literature which included topics such as animal life, puzzles, and biographies. After Indonesia's independence on 17 August 1945, there was an increase both in the number of children's stories and in the number of texts in general for children, all by known authors, mainly because of the Inpres (the presidential instruction) project. In the 1980s, translation works began to dominate, especially those from Europe and America. In the 1990s, Japanese comics became the dominant type of children's reading (Christantiowati 1996: 55; Bunanta 1998: 40-41).

\section{Analysis: loyalty and relationships}

In LKA (Danandjaja 2001), Dewi Pembayun is introduced as a teledek "travelling dancer" and the daughter of Panembahan Senopati Ingalogo, the first Sultan of Mataram. Pembayun's task was to conquer the territory of Ki Ageng Mangir Wonoboyo, leader in 
the Mangir's land who was considered to have defied the Mataram Kingdom. ${ }^{3}$ Seeing Pembayun's gentle face and hands, Wonoboyo apparently became fascinated with her and married her. After becoming the wife of Wonoboyo, Pembayun wiped the magic spear, called "Baru Kelinting", in order to destroy the power of this heirloom. Thereafter, Pembayun reveals her identity and asks Wonoboyo to seek forgiveness from her father. Wonoboyo goes willingly to face Ingalogo. However, he kills Wonoboyo by smashing his face into a rock.

A teledek is a dancer who sings erotic songs while moving rhythmically to attract the attention of men (Koentjaraningrat 1994: 218). Being a teledek was therefore considered a less honourable type of job. However, Pembayun's decision to become a teledek was seen as being loyal to her father's wishes and to her kingdom. This means that she subjected herself to patriarchal power in order to complete the mission her father had assigned her. For Pembayun, being the wife of Wonoboyo was part of a cover to conquer the man who became her father's enemy, displaying not only loyalty but her willingness to act, as she chose the path of a teledek to achieve this aim.

She married in order to fulfil Ingalogo's political ambitions. This practice of getting married with the enemy was common in the Majapahit Kingdom, where marriage was used to maintain the king's power, to take the enemy's heart, or to establish peace. Concerning the politics of marriage, nobles are often regarded as one large family (Lombard 2005: 39). Ingalogo was in charge of making marital decisions, and he decided to marry Pembayun off to Wonoboyo in order to create one large family. On the other hand, Pembayun played a trick of pretending to be in love. Wonoboyo has a powerful spear named Baru Kelinting which will lose its magic if it is rubbed by a woman's cloth belt. In household life in Java, there is usually nothing that should be hidden between husband and wife, even if they have supernatural powers. By becoming Wonoboyo's wife, she was able to uncover his weaknesses, which was the key to removing the problem of the spear Baru Kelinting by rubbing it.

The power of a king is measured by the size of his kingdom and by the various offerings given by the kings of conquered territories. The loyalty of regents and other retainers in carrying out their royal duties is another indication of power. The power of the king is also reflected in the relative extravagance and display of his royal ceremonies, as well as the number of heirlooms he owns, the number of soldiers and weapons he possesses, his wealth, and the various titles given to him (Moedjanto 2002: 79-80). Indeed, as Wulan states (2009: 22), respect for authority is one of the most revered values of the Javanese aristocratic class.

Wonoboyo's power and greatness were marked by his mastery of the Baru Klinting spear, while Ingalogo's power and greatness were indicated by the size of the territory

3 The story related to Pembayun was also written by Pramoedya Ananta Toer (2000) under the title Mangir in the drama genre, 114 pages. In Toer's version, after becoming Wonoboyo's wife, Pembayun declared her loyalty to Wonoboyo and Mangir's land. Pembayun has also become pregnant with Wonoboyo. In front of Ingalogo, Pembayun is also willing to die at Ingalogo's hands. At the end of the story, Pembayun was expelled from the kingdom, and the story closes with the words of Pembayun stating that she is still loyal as Wonoboyo's wife. 
he had conquered, including territories which had once belonged to Wonoboyo. Wonoboyo's marital union with Pembayun in the palace was a sign of submission to Ingalogo, but Ingalogo, the ruler, did not consider it sufficient. Indeed, it was perceived by some that Wonoboyo had undermined the kingdom and therefore had to be killed. There is a loyalty relationship shown by Pembayun, namely loyalty as a wife to Wonoboyo as husband, loyalty as a child to her father Ingalogo, and loyalty as a citizen to the kingdom represented by Ingalogo. For father and kingdom, Pembayun is willing to marry Wonoboyo, eliminating the power of the Baru Kelinting spear, and persuading Wonoboyo to meet Ingalogo as a mark of respect from son-in-law to father-in-law. As a wife, Pembayun admitted that she was not really bad, but was the daughter of Ingalogo. What Pembayun did not expect was that when they met her father, Ingalogo would take the opportunity to kill Wonoboyo.

Regarding women's voices, after Wonoboyo dies, there are no more stories about Pembayun. Pembayun is only used by Ingalogo to subdue his enemies. There is a contradiction in that Pembayun is praised for her sacrifice for the country and for her father, but this also means treachery against the husband, the man who loves her, as written by Dananjaya, ending the story (2001: 34$)$ :

Such is the sacrifice of Pembayun. To defend her kingdom, she was forced to be willing to marry her father's enemy. On the other hand, Wonoboyo had to become a victim because of the betrayal of the woman he loved.

The characteristics highlighted by Pembayun are her sacrifice for the kingdom and her loyalty to her father. For those with aristocratic blood, the priority is loyalty to the family, namely father, mother, younger siblings, and older siblings, in order to protect the breeding and the name of the family. Because this story is aimed at children and is only a few pages long, Pembayun's inner conflicts are not conveyed, and her voice is removed.

Next we analyse representations of women's loyalty in PMK. In PMK (Poerwanto 2009), Pangeran Sambernyowo and his soldiers were chased by Dutch and Kasunanan palace soldiers until they ran out of energy and supplies. They later came across soldiers under the command of Sambernyowo in Turus Village, where they rested. Feeling hungry and thirsty, they joked about offering each other food and drink, as in reality they had no food, only laughter. Sambernyowo, Dipati Kudonowarso, and Ronggo Panambangan found a house belonging to a widow, Mbah Kendil (nicknamed Mbok), who served their entourage not only with water, but with rice as well.

Ricklefs (2018) states that Sambernyowo is considered to be one of the most experienced and talented military leaders in the history of Java, with numerous admirers and loyal followers. The story of PMK is set against the backdrop of war with the Netherlands. The narrative relates that Kendil demonstrated her loyalty to Sambernyowo by giving food to him and his sixty soldiers who were suffering from hunger and thirst. The lines on Mbah Kendil's forehead show clearly that she is older than Sambernyowo. 
The terms "mbok" and "pangeran" refer to social class, as these titles were used to address Mbah Kendil and Sambernyowo, respectively. Kendil belongs to a lower social class than Sambernyowo, as "Mbok" refers to Javanese women of advanced age and of low social class, which means that in the depicted social system she still owes loyalty to Sambernyowo due to his social status, and despite his young age. However, on the other hand, Pangeran or prince is the title given to men of high social class, or of close lineage to the king. Kendil's greatness was demonstrated when only one pot provided enough rice for Sambernyowo and for all his soldiers. The means used by Kendil is an exchange of benefits, providing food and drink for another favour. The promise of a member of the Sambernyowo troop, Ronggo Panambangan, to return the favour indicates that Kendil's action to enhance her social position was successful (Poerwanto 2009: 36):

Before continuing the struggle, Ronggo Panambangan said, "Mbok, once again we all say thank you. For your suit that has helped our struggle, I will return to this village later. I promise to repay your kindness."

In Javanese society, there is a saying "sopo nandur bakal ngunduh", which means whoever plants will get results. Mbok Kendil followed the rules ingrained in this society. People who receive goodness also have the responsibility to provide goodness. ${ }^{5}$ This is the law of reciprocity that is mutually beneficial. This is why Ronggo Panambangan said, "I promise to repay your kindness".

Kendil's action represents three loyalties. First, people's loyalty to their leaders and kingdoms, not to their enemies, namely the Netherlands and the Kasunanan. Second, lower social class loyalty to the upper social class. Third, loyalty and respect from the older generation to the younger generation. Kendil passed away because of age, not because she was killed. After her death, her grave was sacred and respected by the community, which indicates that Kendil is a model that readers should emulate. In the perspective of feminism, how can a woman who has supernatural powers still owe an obligation of loyalty to the kingdom and its leaders, in this case, the male gender?

We will now analyse representations of loyalty in MSB (Yudiono \& Mulyono 2005). In MSB, it is stated that Nyai Sutawanengraga is a woman from a poor background. In a battle between Patih Pragola and Panembahan Senopati Mataram, Sutawanengraga saved Pragola's child. The action of Sutawanengraga is not only an act of courage to save the son of the Kadipaten of Pati [the Duchy of Pati, or the Pati Regency], but it also shows how she was thinking of the future: "Who knows if someday it will still be possible for Pragola's child to return to the throne when things improve" (Yudiono \& Mulyono 2005: 27).

In the past, Sutawanengraga had saved a child belonging to a family of the Kadipaten of Pati. Sutawanengraga was loyal to her homeland, the Kadipaten of Pati, who were the opponents of the Mataram Kingdom. In the story of MSB, there is a relationship between Sutawanengraga and a child that came from the Kadipaten of Pati. Sutawanengraga

\footnotetext{
4 All the excerpts from the analysed stories are translated by the author of this paper.

5 This exchange of kindness received an in-depth analysis in Robert Cialdini's (2005) book.
} 
belonged to a lower social class than the child who came from the Kadipaten of Pati. Indeed, Sutawanengraga was a peasant and a commoner. Sutawanengraga was also twice the age of the child from the Kadipaten of Pati, which was apparent from the wrinkles on her face. Her body is described as noticeably weak. Sutawanengraga is a poor woman. It is not known whether she had children or a family. She is depicted alone and has nothing. As shown in the narrative, Sutawanengraga engages in some exchange to gain benefit. As part of her exchange action, Sutawanengraga amasses cultural and economic benefit through the lives of those from the Kadipaten of Pati so as not to become extinct. She desires to increase her gains by exchanging her loyalty. "Possibly being able to return to the throne when things improve" can be interpreted as a hope that Pragola's child can become king again in the future and repay her kindness.

Sutawanengraga's actions also represent three loyalties found in Kendil, namely loyalty to the leader and the kingdom, to the upper social class, and to the younger generation. What distinguishes Sutawanengraga is that she is not a woman who has supernatural powers like Kendil. Sutawanengraga is just an ordinary woman. In addition, Sutawanengraga passed away when Pragola’s descendants were not kings or leaders.

Table 1. Loyalty Action

\begin{tabular}{ll}
\hline Subject & Action \\
\hline Dewi Pembayun & Became a teledek and the wife of a political enemy \\
\hline Mbah Kendil & Provided food \\
Sutawanengraga & Saved the descendants of the king \\
\hline
\end{tabular}

To sum up, the actions of Sutawanengraga, Mbah Kendil, and Pembayun (Table 1) are in line with the conventional understanding of loyalty as fulfilling royal duties, as women are obliged to be loyal to the authorities in the traditional system of values in Indonesian culture. What necessarily happened when women were disloyal will be explained in the next section.

\section{Resistance and punishment}

How does power in Java treat women who are not loyal and resist authority? What punishments will a disloyal female subject receive?

In DSS (Kusaeri 2009), foreigners who came to the Majapahit Kingdom, Dewi Siti Kolifah, her sister Sukowati, and her brother Agus Salim, visit Rembang in the Sluke area. Sukowati and Salim have a role in helping Kolifah's wishes come true. They will worship and seek water but cannot find a source of water. Kolifah, with magical power, created one. Together with the members of the surrounding community, between Kolifah and the indigenous population, they formed a kingdom called Seringin (Kusaeri 2009: 173): 
Next, the newcomers and indigenous people can come together. They can also form a community. Even over time they can develop into a large community, which eventually turns into a small kingdom called the Seringin Kingdom, led by a queen named Dewi Siti Kolifah.

The emergence of this new kingdom was of concern to Prabu Brawijaya, the ruler of Majapahit, who immediately sent the warlord Haryo Damar to destroy the Seringin Kingdom (Kusaeri 2009: 174):

Because Prabu Brawijaya did not want his power to be challenged, the King immediately ordered his troops to destroy the Seringin Kingdom and sent Majapahit soldiers led by a warlord named Haryo Damar. The arrival of soldiers from the Majapahit Kingdom in the Seringin Kingdom led inevitably to war between the Majapahit soldiers and Kolifah's followers.

During the war, Kolifah, who was disguised as a man named Jaka Samaran, intended to establish the Seringin Kingdom and become queen. She did all this in order to rival the power of the Majapahit Kingdom.

In DSS, Damar is the messenger and deputy king of Majapahit. Kolifah belongs to a lower social class than Damar, who represents the Majapahit Kingdom. Kolifah is a dissident in the eyes of the Majapahit Kingdom. However, the ages of Kolifah and Damar are unclear to begin with, as only at the end of the story is it indicated that they are of a similar age. Damar did not know that the person in disguise was Kolifah. During the battle, Damar managed to injure Samaran with his spear. Damar is shocked to find out that the wounded person in disguise is Kolifah. Kolifah passed away in Damar's arms. Damar calls Kolifah a "beautiful woman" and also states that he "immediately helped Kolifah". Damar regretted his actions. In this section, Damar is seen both as a soldier who kills his enemy and as a young man who is attracted to female beauty.

Kolifah employs a strategy directed toward increasing her power by establishing a kingdom to rival the Majapahit Empire. The courage of Kolifah conforms to popular notions of Indonesian women who sought financial liberation so that they could gain social independence in the early twenty-first century (Purbani 2013: 373). Kolifah's courage also conforms to Harjito's (2017) findings that women with supernatural powers are often called upon to defeat humans with undesirable traits, such as anger, ruthlessness, arrogance, and cruelty, in order to turn them into noble characters who are calm, forgiving, polite, and humble. Haase (2004: 1-2) highlights the role of feminist fairy-tale scholarship to detect strong female characters that are competent, resourceful and powerful and which put folktales into a group of a few sorts of classic children's literature which would be approved by radical feminists. On the other hand, according to Haase, female characters are almost non-existent in most award-winning picturebooks and, if present, they are stereotypically passive and domestic. However, Dewi Siti Kolifah's actions were contrary to the stereotypical images of women referred to in Serat Suluk Redriya, ${ }^{6}$ according to which Javanese women are helpless without the

${ }^{6}$ This is a Javanese literary work based on Islamic tradition, containing the teachings of Sufism, but also has an insert of behavioural teachings for women, for example that Javanese women must be loyal and devoted to their husbands. 
support of a man (Widyastuti 2014: 121). The norms of the Indonesian culture demand that women obey their husbands and submit themselves to their will, as their primary duty is to take care of their husbands and children (Liliani and Esti Swatika Sari 2010: 47). However, at the end of the story, Kolifah passes away: "When Siti Kolifah was in Haryo Damar's arms to be rescued, Kolifah took her last breath as she arrived at the edge of the river" (Kusaeri 2009: 177).

Power is exerted by removing people or groups that are considered threats to the king (Moedjanto 2002: 87; Munoz 2009: 382). This is the sole reason why Kolifah is killed by the Majapahit Kingdom. Kolifah's actions were similar to those of Wonoboyo. Indeed, both were disloyal to the kingdom. They also both resisted the authorities and committed actions meant to undermine the kingdom. The result was death, with Wonoboyo's head being smashed on a rock. Kolifah was also killed in a similar fashion, dying in the lap of Damar, who was the messenger of the Majapahit Kingdom. Loyalty does not recognise gender and the demand of loyalty to the state applies to both men and women, so they are both punished if they resist and violate it.

\section{Women's voices: marginalised voices}

At least two things can show whether a woman's voice is considered. One is a comparison of the number of women and men characters. Another is how they take sides at the end of the story. The number of women and men characters can be seen in Table 2 .

Table 2. Numbers of women characters

\begin{tabular}{ccc}
\hline Title & Number of Women & Number of Men \\
\hline MSB & 1 & 1 \\
\hdashline LKA & 1 & 1 \\
\hdashline PMK & 1 & 3 \\
\hdashline DSS & 1 & 3 \\
\hline
\end{tabular}

From Table 2, it can be seen that in the analysed stories, except for MSB, the number of men is larger than the number of women. In MSB, the woman is Sutawanengraga, while the man is Suto Bodo. Three stories are illustrated by one image each, while the analysed edition of DSS does not include any pictures. In MSB, the number of women and men is the same, i.e., there is one of each. In LKA, three men, i.e., Pangeran Sambernyowo, Dipati Kunonowarso, and Ronggo Panambangan are confronted with one woman, namely Mbah Kendil. In the illustration, there is one woman and five men. In PMK, three men, Panembahan Senopati Ingalogo, Wonoboyo, and Ki Juru Martani, appear compared to only one woman. The same ratio appears in the illustration. In DSS, 
there are two men characters, Prabu Brawijaya and Haryo Damar, and one woman, Siti Kolifah.

The endings of these stories often reflect a normative judgment concerning the protagonist's actions and how they relate to the concept of loyalty or disloyalty.

The ending of Dewi Pembayun's story was not clearly stated, as it is difficult to determine what benefit Pembayun has obtained after she succeeded in conquering the heart of Wonoboyo (Danandjaja 2001: 34):

Ki Ageng Mangir Wonoboyo headed to Mataram accompanied by Dewi Pembayun and several guards.

$[\ldots]$

However, unexpectedly and suddenly, Panembahan Senopati Ingalogo holds the head of Wonoboyo and with all his might bangs his son-in-law's head against a hard stone floor called a rock "Gilang", immediately killing Wonoboyo.

Despite Pembayun having watched Wonoboyo die, the activities of Pembayun after this remain unknown, as they are not documented in the story. Although the sacrifice of Pembayun had been forgotten, she was still alive at the end of the story, unlike Sutawanengraga. The peasant who helped the child, Sutawanengraga, saved the child's life not only by providing some goods, but also by providing cultural capital in the form of knowledge about life. This action is visible at the end of the story, which mentions Kendil obtaining certain direct benefits, and also social ones. At the end of the story, the community and relatives of Kendil receive recognition. In addition, the descendants of Kendil become government employees, which represents some goods in the form of services to her people and social status (Poerwanto 2009: 37):

For the services of Mbah Kendil, the people of Turus and relatives of Mbah Kendil received services from Raden Ronggo Panambangan. Many government employees are the descendants of people from this area. After her death, Mbah Kendil was buried in the village of Turus. Her grave is marked Punden Mbah Kendil and until now has been revered by the surrounding community.

However, Kendil did not get a direct benefit, although the descendants of Kendil did benefit from her actions. Hence, Kendil received only a symbolic reward in the form of the grave, which was sacred. What has been discussed can be noted in Table 3.

Table 3. Final outcomes in stories on loyalty

\begin{tabular}{|c|c|c|c|}
\hline Female character & $\begin{array}{l}\text { Advantages of } \\
\text { Rulers }\end{array}$ & $\begin{array}{l}\text { Advantages of } \\
\text { Subjects }\end{array}$ & $\begin{array}{l}\text { The protagonist's fate } \\
\text { at the end of the story }\end{array}$ \\
\hline Dewi Pembayun & $\begin{array}{l}\text { Gets rid of political } \\
\text { opponents }\end{array}$ & Not told & Not known \\
\hline Sutawanengraga & $\begin{array}{l}\text { Finds king's } \\
\text { descendants }\end{array}$ & There is no advantage & Dies in poverty \\
\hline Mbah Kendil & $\begin{array}{l}\text { Able to continue the } \\
\text { struggle }\end{array}$ & $\begin{array}{l}\text { Descendants become } \\
\text { government employees }\end{array}$ & $\begin{array}{l}\text { Dies and the tomb is } \\
\text { respected }\end{array}$ \\
\hline Siti Kolifah & Undermined & Becomes a queen & Killed \\
\hline
\end{tabular}


Women's loyalty toward the authorities is related in terms of certain gains or benefits, as women and rulers exchange goods and privileges with each other. However, it is uncertain if the relationships are mutually beneficial to both parties.

Kendil received economic and symbolic benefits, while her descendants and relatives became government employees. Kendil's grave was revered by the community; however, Sutawanengraga and Pembayun did not obtain any reward in recompense for their loyalty. Pembayun's fate was also unknown, as it is not told in the story. Sutawanengraga also passes away before the child who, coming from the Kadipaten of Pati, later became the king. In contrast, the authorities always receive more symbolic gains in the form of honour and esteem.

In reality, the ruler or holder of power cannot be distinguished from institutions or individuals. Rulers and holders represent the nation or kingdom and are therefore identical to institutions. Loyalty to institutions is commensurate with loyalty to the powerful.

Based on the end of the stories of Sutawanengraga and of Pembayun, despite fulfilling the expectations of loyalty to the authorities, their fate was unimportant, highlighting that these texts were produced from the point of view of rulers. The resistance exhibited by women such as that carried out by Kolifah further emphasises that there is an obligation for women to be loyal to the kingdom and, in particular, to the authorities. However, the obligations of the ruler or kingdom with regard to women's loyalty are not mentioned and seem to be unimportant.

\section{Child readers}

Children who enjoy folk tales are usually between the ages of six and twelve. An indication that a text is intended for children's reading can be established from the number of pages. If the number of pages is more than one hundred, it can be assumed that it is not aimed at children (Bunanta 1998: 28, 65). In the present day, the number of pages can be replaced by the estimated number of words or the number of letters. We have calculated the number of pages, words and images in each of the books to establish if they address child readers, according to the above criteria (Table 4).

Table 4. Word and Picture

\begin{tabular}{|c|c|c|c|}
\hline Title & Number of pages & Number of words & Illustrations \\
\hline MSB & 5 & 1016 & 1 \\
\hline LKA & 6 & 1056 & 1 \\
\hline PMK & 5 & 916 & 1 \\
\hline DSS & 10 & 1404 & - \\
\hline
\end{tabular}


The four stories are contained in a book each, each measuring $14 \times 21 \mathrm{~cm}$. In the edition of DSS, the number of pages and the number of words are larger than in the editions of the other stories, and no images are included because the text is published by a non-commercial publisher.

The fact that these four Indonesian folktales are addressed to children is perhaps more convincingly supported by paratexts, such as the indication of the readers' age in the Introduction which includes a greeting to "children", as in the copies of LKA and PMK (Danandjaja 2001: vi; Poerwanto 2009: vi). On the back cover of LKA and MSB, there is also the publisher's note that "The interesting and simple manner of presentation makes this book appropriate for children" (Danandjaja 2001; Yudiono \& Mulyono 2005).

Furthermore, thesekinds of folktales are believed to play a major role in contributing to the development of a child's personality and maturity (Nurgiyantoro 2004: 213). On the back cover of LKA, the publisher mentions that "This story was compiled by an expert who takes into account the moral message contained in it" (Danandjaja 2001). The author of DSS conveys in the foreword that one of the goals of a story written or published is to "cause mutual respect and ultimately to be able to accumulate a sense of national unity in our territory" (Kusaeri 2009: iv). The authors and publishers have intentionally retold folktales which send a message of preserving the traditional roles of women in Indonesian society regarding their obligation to be loyal and submissive, failing which they would deserve punishment.

Besides, at the end of the text, there is a kind of conclusion or note submitted by the author(s). Yudiono and Mulyono (2005: 30) write that "awareness of the history of the struggle of ancestors needs to be developed". Poerwanto (2009: 37) states that "this text tells of the power of a widow who can feed sixty-three people with one pot of rice". Dananjaja (2001: 34-35) mentions that "this story is very good because it teaches us how a young woman has sacrificed herself to defend the authority of her father and the integrity of his country, even though in a dishonourable way". These quotations further support our conclusion on the intentional ideological influence these authors wish to exert on their child readers.

All these notes represent values that are considered important by the authors and

they agree that such messages need to be conveyed to children through traditional Indonesian stories. All of them are conveyed by means of a common theme: the loyalty of women to the state.

\section{Conclusions}

Based on the above analysis, conclusions can be drawn regarding the loyalty of Javanese women as represented in Indonesian folktales for children. Firstly, Javanese women are obligated to be loyal to the authorities, institutions, as well as kingdoms or countries. Secondly, questions of loyalty are intertwined with the action of Javanese women to exchange or gain goods and benefits. Besides, the Javanese women characters presented in the analysed tales made calculations regarding economic and symbolic 
benefits when deciding whether to be loyal, similarly to their rulers. Next, women's voices are voices that are still marginalised. The texts do not present many women's voices. They are all male. Lastly, Javanese women who were disloyal or who resisted ended up being destroyed by the authorities. In relation to child readers, loyalty to the authorities or state seems to be a significant thematic area intended for children as a model of behaviour and decision making, especially in literature about girls.

Recent publications of folktales persist in promoting the traditional patriarchal system of values which tends to limit the agency of women. Some of them appear as cautionary tales that threaten punishment if girls or women resist the kind of loyalty which involves obedience to those who are placed above them in the social scale, whether men, classes, or institutions. Javanese girls and women in Indonesian folktales for children are represented as being expected to show loyalty both to men in their surrounding and to rulers and institutions, which are functionally the same. The representations of women's voices are rare and the voices that resist tradition are silenced by punishment.

Such messages in the analysed texts, advocating obedience, show that their authors have failed to promote the values and practices encountered through the greater engagement of women in contemporary Indonesian society. The opportunity to encourage young readers, especially girls, to assume responsibility and ensure their active position in society, education, politics and in their everyday life has not been taken in the analysed texts.

\section{References}

\section{Primary sources}

Danandjaja, James. 2001. Legenda Ki Ageng Mangir Wonoboyo [The Legend of Ki Ageng Mangir Wonoboyo]. In Cerita Rakyat dari Jawa Tengah [Folklore from Central Java]. Jakarta: Grasindo.

Kusaeri, Yusuf Sudarno. 2009. Dewi Siti Sarijati [Miss Siti Sarijati]. In Dongeng Rakyat Kabupaten Rembang Jilid 1 [Folklore of Rembang Regency Volume 1]. Rembang: CV Duta Mulia.

Poerwanto, Parpal. 2009. Punden Mbah Kendil [Grandma Kendil's Grave]. In Cerita Rakyat dari Wonogiri (Jawa Tengah) [Folk Story from Wonogiri (Central Java)]. Jakarta: Grasindo.

Yudiono and Mulyono. 2005. Mbah Suto Bodo [Suto Bodoss Grandma]. In Cerita Rakyat dari Pati (Jawa Tengah) [Folk Story from Pati (Central Java)]. Jakarta: Grasindo.

\section{Secondary sources}

Bandel, Katrin. 2013. Perempuan Jawa dalam Cerpen Pramoedya Ananta Toer dan Umar Kayam [Javanese Woman in Pramoedya Ananta Toer's Short Story and Umar Kayam]. In Sastra Nasionalisme Pascakolonialitas [Literature Nationalism Post-Colonialism], 79-96. Jogyakarta: Pustaha Hariara.

Bunanta, Murti. 1998. Problematika Penulisan Cerita Rakyat untuk Anak di Indonesia [The Problems of Writing Folklore for Children in Indonesia]. Jakarta: Balai Pustaka.

Carey, Peter and Vincent Houben. 2016. Perempuan-Perempuan Perkasa di Jawa Abad XVIIXIX [Mighty Women in Java in the XVII-XIX Century]. Transl. Peter Carey. Jakarta: Gramedia. 
Christantiowati. 1996. Bacaan Anak Indonesia Tempo Doeloe Kajian Pendahuluan Periode 1908-1945 [Readings of Indonesian Children in the Past, Preliminary Studies for the Period 1908-1945]. Jakarta: Balai Pustaka.

Cialdini, Robert. 2005. Psikologi Persuasif Merekayasa Kepatuhan [The Psychology Influence of Persuasion]. Transl. Tri Wibowo Budi Santoso. Jakarta: Prenada Media.

Clark, Roger. 2002. Why All the Counting? Feminist Social Science Research on Children's Literature. Children's Literature in Education 33 (4): 285-295.

Damono, Sapardi Djoko. 2003. Sosiologi Sastra [Sociology of Literature]. Semarang: Magister Ilmu Susastra Program Pascasarjana Universitas Diponegoro.

Haase, Donald. 2004. Feminist Fairy-Tales Scholarship. In Fairy Tales and Feminism: New Approaches, 1-36. Michigan: Wayne State University Press.

Harjito. 2014. Kemandirian Perempuan Jawa dalam Cerita Tradisional [The Independence of Javanese Women in Traditional Stories]. Litera, Jurnal Penelitian Bahasa, Sastra, dan Pengajarannya 13 (2): 316-325.

Harjito. 2016. The Relationship Between Javanese Women and Their Daughter in Indonesian Literature. The Social Sciences 11 (27): 6497-6503.

Harjito. 2017. Supernatural Women Modernity in Indonesian Literature. Asian Social Science 13 (10): 65-74.

Humm, Maggie. 2009. Teori Sastra Feminis [Feminist Literary Theory]. Pengantar TeoriTeori Feminis Kontemporer [Introduction to Contemporary Feminist Theories], ed. by Stevi Jackson and Jackie Jones, Transl. Jalasutra Translation Team, 331-362. Yogyakarta: Jalasutra.

Ismawati, Esti. 2013. Karakter Perempuan Jawa dalam novel Indonesia Berwarna Lokal Jawa: Kajian Perspektif Gender dan Tranformasi Budaya [The Character of Javanese Women in Indonesian Novels Javanese Local Color: Study of Gender Perspectives and Cultural Transformation]. Metasastra 6 (1): 10-21.

Koendtjaraningrat. 1994. Kebudayaan Jawa [Javanese Culture]. Jakarta: Balai Pustaka.

Liliani, Else and Esti Swatika Sari. 2010. Refleksi Perempuan dalam Novel Indonesia 19002000 [Reflections on the Role of Women in Indonesian Novels 1900-2000]. Litera, Jurnal Penelitian Bahasa, Sastra, dan Pengajarannya 9 (1): 40-51.

Lombard, Denys. 2005. Nusa Jawa: Silang Budaya 3 Warisan Kerajaan-Kerajaan Konsentris. [Nusa Java: Cultural Cross 3 Inheritance of Concentric Kingdoms]. Transl. Winarsih Partaningrat Arifin, Rahayu S Hidayat, and Nin Hidayati Yusuf. Jakarta: Gramedia.

Lukens, Rebecca J. 2003. A Critical Handbook of Children's Literature. Boston: Perason Education.

Moedjanto. 2002. Konsep Kekuasaan Jawa Penerapannya oleh Raja-Raja Mataram [Javanese Power Concept: Its Application by the Kings of Mataram]. Yogyakarta: Kanisius.

Munoz, Paul Michel. 2009. Kerajaan-Kerajaan Awal Kepulauan Indonesia dan Semenanjung Malaysia [Early Kingdoms of the Indonesian Archipelago and the Malay Peninsula]. Transl. Media Abadi Team. Yogyakarta: Mitra Abadi.

Nurgiyantoro, Burhan. 2004. Kontribusi Sastra Anak dalam Pembentukan Kepribadian anak [The Contribution of Children's Literature in the Formation of Children's Personality]. Cakrawala Pendidikan (2): 203-231.

Nurgiyantoro, Burhan. 2005. Sastra Anak: Pengantar Pemahaman Dunia Anak [Children's Literature: Introduction to the Understanding of the Children's World]. Yogyakarta: Gadjah Mada Univerity Press.

Pocha, Sophia. 2010. Feminisme dan Gender [Feminism and Gender]. In Pengantar Memahami Feminisme \& Postfeminisme [Introduction to Understanding Feminism \& Postfeminism], ed. by Sarah Gamble, Transl. Jalasutra Translation Team, 69-81. Yogyakarta: Jalasutra. 
Purbani, Widyastuti. 2013. Watak dan Perjuangan Perempuan dalam Novel-Novel Karya Penulis Perempuan Indonesia dan Malaysia Awal Abad 21 [The Character and Struggle of Women in Novels by Indonesian and Malaysian Women's Writers in the Early $21^{\text {st }}$ Century]. Litera, Jurnal Penelitian Bahasa, Sastra, dan Pengajarannya 12 (2): 367-380.

Pusat Bahasa Departemen Pendidikan Nasional. 2008. Kamus Bahasa Indonesia [Indonesian Dictionary]. Jakarta: Pusat Bahasa Departemen Pendidikan Nasional.

Ricklefs, Merle Calvin. 2009. Sejarah Indonesia Modern 1200-2008 [A History of Modern Indonesia 1200-2008]. Transl. Serambi Translation Team. Jakarta: Serambi Ilmu Semesta.

Ricklefs, Merle Calvin. 2018. Asal-Usul Pangeran Samber Nyawa [The Origin of Pangeran Samber Nyawa]. Historia. <https://historia.id/politik/articles/asal-usul-pangeransamber-nyawa-P4Wjn> (accessed 31 July 2018).

Riff, Michael A. 2001. Kamus Ideologi Politik Modern [Dictionary of Modern Political Ideology]. Yogyakarta: Pustaka Pelajar.

Sargent, Lyman Tower. 1987. Ideologi-Ideologi Politik Kontemporer Sebuah Analisis Komparatif. [Contemporary Political Ideologies A Comparative Analysis]. Transl. Henry Sitanggang. Jakarta: Erlangga.

Toer, Pramoedya Ananta. 200. Mangir. Jakarta: Kepustakaan Populer Gramedia.

Tong, Rosemare Putnam. 2008. Feminist Thought: Pengantar Paling Komprehensif kepada Aliran Utama Pemikiran Feminis [Feminist Thought: The Most Comprehensive Introduction to the Main of Feminist Thought]. Transl. Aquarini Priyatna Prabasmoro. Yogyakarta: Jalasutra.

Udasmoro, Wening. 2011. Pengantar Gender dalam Sastra [Introduction to Gender in Literature]. Yogyakarta: Fakultas Ilmu Budaya Universitas Gadjah Mada.

Widyastuti, Sri Harti. 2014. Kepribadian Wanita Jawa dalam Serat Suluk Residriya dan Serat Wulang Putri Karya Paku Buwono IX [Javanese Women's Personality in Serat Suluk Residriya and Serat Wulang Putri by Paku Buwono IX]. Litera, Jurnal Penelitian Bahasa, Sastra, dan Pengajarannya 13 (1): 114-127.

Wulan, Nur. 2009. Masculinities in Colonial Indonesian Children's Literature. Explusutra (The Postgraduate Ejournal of the WUN International Network in Colonial and Postcolonial Studies) 1: 7-24.

Young, Shelagh. 2010. Feminisme dan Politik Kekuasaan: Sebenarnya, Tatapan Siapa? [Feminism and Power Politics: Actually, Whose Gaze?]. In Tatapan Perempuan. Perempuan Sebagai Penonton Budaya Populer [Women's Gaze. Women as Viewers of Popular Culture], ed. by Lorrainde Gamman and Margaret Marsment, Transl. Bethari Anissa Ismayasari, 261-282. Yogyakarta: Jalasustra.

\section{Harjito}

Sveučilište Udruge učitelja Republike Indonezije, Semarang, Središnja Java, Indonezija

\section{Odanost i javanske žene $u$ indonezijskim folklornim pričama za djecu}

U istraživanju se analizira zastupljenost odanosti javanskih žena u indonezijskim folklornim pričama. Analiza četiriju priča oslanja se na tekstualnu raščlambu iz feminističke perspektive te na odabrane elemente književno-sociološkoga pristupa. Zaključuje se da su javanske žene $\mathrm{u}$ indonezijskim narodnim pričama dužne biti odane vladarima i institucijama - koji su zapravo jedno te isto. Javanke koje iskazuju lojalnost često su nagrađene simboličnim 
nagradama i prednostima, dok one nelojalne ili prkosne čeka tragičan kraj. Analizirani tekstovi ne uključuju ženske glasove. Indonezijske narodne priče stoga mladim čitateljima, a osobito djeci, prenose uvjerenje da je odanost državi i vlastima od iznimne važnosti.

Ključne riječi: odnos, zastupanje, ovlasti, kontekst, glas 